Research Article

\title{
Chemical, Bioactive, and Antioxidant Potential of Twenty Wild Culinary Mushroom Species
}

\author{
S. K. Sharma ${ }^{1}$ and N. Gautam ${ }^{2}$ \\ ${ }^{1}$ Department of Plant Pathology, CSK, Himachal Pradesh Agriculture University, Palampur 176 062, India \\ ${ }^{2}$ Centre for Environmental Science and Technology, School of Environment and Earth Sciences, Central University of Punjab, \\ Bathinda 151 001, India \\ Correspondence should be addressed to N. Gautam; ngautam86@gmail.com
}

Received 8 May 2015; Accepted 11 June 2015

Academic Editor: Miroslav Pohanka

Copyright (C) 2015 S. K. Sharma and N. Gautam. This is an open access article distributed under the Creative Commons Attribution License, which permits unrestricted use, distribution, and reproduction in any medium, provided the original work is properly cited.

The chemical, bioactive, and antioxidant potential of twenty wild culinary mushroom species being consumed by the people of northern Himalayan regions has been evaluated for the first time in the present study. Nutrients analyzed include protein, crude fat, fibres, carbohydrates, and monosaccharides. Besides, preliminary study on the detection of toxic compounds was done on these species. Bioactive compounds evaluated are fatty acids, amino acids, tocopherol content, carotenoids ( $\beta$-carotene, lycopene), flavonoids, ascorbic acid, and anthocyanidins. Fruitbodies extract of all the species was tested for different types of antioxidant assays. Although differences were observed in the net values of individual species all the species were found to be rich in protein, and carbohydrates and low in fat. Glucose was found to be the major monosaccharide. Predominance of UFA (65-70\%) over SFA (30-35\%) was observed in all the species with considerable amounts of other bioactive compounds. All the species showed higher effectiveness for antioxidant capacities.

\section{Introduction}

Wild mushrooms have long been considered as highly nutritious tasty food items from ancient time [1-3]. Besides nutritional importance wild edible mushrooms are now well known for their pharmaceutical constituents $[4,5]$. Presently, there are several mushroom species which have established therapeutic properties [6-11]. In addition, mushroom extract is considered as important remedies for the prevention and treatment of many diseases for thousands of years in several parts of the world $[12,13]$. Mushrooms are known to contain immunomodulating compounds which help to improve immune function in cancer patients during radio and chemotherapy and help to prolong survival times in some types of cancer [14]. Another aspect of mushrooms is lowering blood pressure and free cholesterol in plasma [15]. Major bioactive compounds extracted from mushrooms are well known for their antioxidant [16], antitumor, and antimicrobial properties [17]. The nutritive nutraceuticals present in mushrooms are dietary fibres, polyunsaturated fatty acids (PUFA), proteins, amino acids, keto acids, minerals, antioxidative vitamins, and other antioxidants [18-20].
Currently 14,000 mushroom species are known to exist. Out of these, about $50 \%$ species are reported to possess varying degrees of edibility and almost 3000 species spread over 31 genera are regarded as prime edible mushrooms. To date only 200 of them are experimentally grown, 100 of them are economically cultivated, approximately 60 are commercially cultivated, and about 10 have reached industrial scale production in many countries [21]. Furthermore, about 2000 are medicinal mushrooms with variety of health benefits and 270 species are now considered as potential therapeutic or preventative agents that are ensured for human health perspective. The poisonous mushrooms are relatively small in number (approximately 1\%) but there is an estimate that about $10 \%$ may have poisonous attributes while 30 species are considered to be lethal [21].

The northern Himalayan regions of India include the states of Himachal Pradesh $\left(30^{\circ} 22^{\prime}\right.$ to $33^{\circ} 12^{\prime} \mathrm{N}$ latitude and $75^{\circ} 45^{\prime}$ to $79^{\circ} 04^{\prime} \mathrm{E}$ longitude), Uttarakhand $\left(28^{\circ} 43^{\prime} \mathrm{N}\right.$ to $31^{\circ} 28^{\prime} \mathrm{N}$ latitude and $77^{\circ} 34^{\prime} \mathrm{E}$ to $81^{\circ} 03^{\prime} \mathrm{E}$ longitude), and some parts of Jammu and Kashmir $\left(34^{\circ} 8^{\prime} \mathrm{N}\right.$ and $\left.77^{\circ} 34^{\prime} \mathrm{E}\right)$. The regions in these states have extensive areas under forest 
cover (i.e., more than 50\%). The people of these areas use different mushroom species for culinary purposes. They have very little idea about the medicinal importance of these mushroom species. Their methods of identification are primarily based upon sweet smell and color. Further, the knowledge about the edible species is restricted to the old aged people. Documentations studies of these edible species have been done by several workers [22] but the studies on chemical composition and medicinal importance are still lacking besides the presence of toxic compounds in them. In view of this, under present investigations twenty of such wild culinary mushroom species have been evaluated for their chemical, bioactive, and antioxidant potential.

\section{Materials and Methods}

2.1. Collection and Processing of Samples. All the samples were collected during the frequent surveys to the different regions of northern Himalayas (Table 1). After this, the samples were vacuum-dried and preserved in air-tight cellophane bags, with a small amount of 1-4-paradichlorobenzene in porous packets to keep them free of insects, for further analysis.

2.2. Chemical Evaluation. Samples were powdered and evaluated for protein, fat, carbohydrates, ash, and crude fibres. Crude protein content was estimated using the Kjeldahl method by calculating total nitrogen $(\mathrm{N})$ and protein content was expressed by $\mathrm{N} \times 4.38$ [23]. Crude fat was estimated using a Soxhlet apparatus by extraction of known weight of powered samples with petroleum ether. Ash content was calculated by incineration in silica dishes at $525 \pm 20^{\circ} \mathrm{C}$ containing 5-10 g/sample. Fibres content was estimated on a fatfree sample using the acid-alkali method (1.25\% each). Total carbohydrates percentage was calculated by the difference as the total weight - (moisture content + protein content + crude fat + ash content + crude fibres).

For toxic metal detection, diluted $\mathrm{HCl}(2 \%)$ and copper foil $(1 \times 1 / 2 \mathrm{~cm}$ strip, purified or pretreated with concentrated $\mathrm{HNO}_{3}$ or diluted $3 \mathrm{HCl}$ and rinsed in distilled water) were taken. After that samples (powered samples) were acidified with $10-20 \mathrm{~mL}$ of 5 diluted $\mathrm{HCl}(2 \%)$ until colour changed from fairy pink to litmus. Then strips of copper foil were added and boiled for 30 minutes with addition of water from time to time to replace the losses by evaporation. The heavy metals got deposited on the copper foil and gave characteristics color to it. The color deposited on the $\mathrm{Cu}$ foil was noted after 30 minutes and results were interpreted for the presence of heavy metals [24].

For monosaccharide composition, samples $(0.1 \mathrm{~g})$ were extracted with $2.5 \mathrm{~mL}$ and $1.5 \mathrm{~mL}$ and finally with $1 \mathrm{~mL}$ of $70 \%$ aqueous methanol. After this, the extract was centrifuged at $4000 \mathrm{rpm}\left(4^{\circ} \mathrm{C}\right)$ for $10 \mathrm{~min}$. Supernatant was collected and volume was made up to $5 \mathrm{~mL}$ with $70 \%$ methanol. The extract was passed through Millipore filter $(0.45 \mu \mathrm{m})$ and injected to the HPLC [24].

\subsection{Bioactive Evaluation}

2.3.1. Fatty Acid Composition. Powdered samples were dissolved in $1 \mathrm{~mL}$ of solution (prepared by sodium hydroxide
TABLE 1: List of wild culinary species collected from different localities of twenty species from northern Himalayas.

\begin{tabular}{|c|c|c|}
\hline Species & Collection locality & $\begin{array}{l}\text { Altitude } \\
\text { (meters) }\end{array}$ \\
\hline Agaricus arvensis & Shimla (Himachal Pradesh) & 2300 \\
\hline A. campestris & Kullu (Himachal Pradesh) & 2200 \\
\hline A. comtulus & $\begin{array}{l}\text { Jhatingri (Himachal } \\
\text { Pradesh) }\end{array}$ & 2300 \\
\hline A. silvicola & $\begin{array}{l}\text { Dharamshala (Himachal } \\
\text { Pradesh) }\end{array}$ & 1800 \\
\hline Amanita caesarea & $\begin{array}{l}\text { Janjehli (Himachal } \\
\text { Pradesh) }\end{array}$ & 2500 \\
\hline A. citrine & $\begin{array}{l}\text { Mcleodganj (Himachal } \\
\text { Pradesh) }\end{array}$ & 2000 \\
\hline A. fulva & $\begin{array}{l}\text { Mcleodganj (Himachal } \\
\text { Pradesh) }\end{array}$ & 2000 \\
\hline Cantharellus cibarius & $\begin{array}{l}\text { Khajjiar (Himachal } \\
\text { Pradesh) }\end{array}$ & 2400 \\
\hline Conocybe tenera & Kufri (Himachal Pradesh) & 2400 \\
\hline Gymnopilus junonius & Nanital (Uttarakhand) & 2300 \\
\hline Hygrocybe coccinea & $\begin{array}{l}\text { Jhatingri (Himachal } \\
\text { Pradesh) }\end{array}$ & 2300 \\
\hline H. nivea & $\begin{array}{l}\text { Dharamshala (Himachal } \\
\text { Pradesh) }\end{array}$ & 1800 \\
\hline Inocybe splendens & $\begin{array}{l}\text { Sonamarg (Jammu and } \\
\text { Kashmir) }\end{array}$ & 2800 \\
\hline Lactarius pubescens & $\begin{array}{l}\text { Mcleodganj (Himachal } \\
\text { Pradesh) }\end{array}$ & 2000 \\
\hline Laccaria laccata & $\begin{array}{l}\text { Mcleodganj (Himachal } \\
\text { Pradesh) }\end{array}$ & 2000 \\
\hline Lepista nuda & $\begin{array}{l}\text { Khajjiar (Himachal } \\
\text { Pradesh) }\end{array}$ & 2400 \\
\hline Lentinus cladopus & $\begin{array}{l}\text { Bhadrol (Himachal } \\
\text { Pradesh) }\end{array}$ & 1200 \\
\hline Pleurotus cystidiosus & $\begin{array}{l}\text { Palampur (Himachal } \\
\text { Pradesh) }\end{array}$ & 1400 \\
\hline Russula lepida & $\begin{array}{l}\text { Mcleodganj (Himachal } \\
\text { Pradesh) }\end{array}$ & 2000 \\
\hline R. mairei & $\begin{array}{l}\text { Mcleodganj (Himachal } \\
\text { Pradesh) }\end{array}$ & 2000 \\
\hline
\end{tabular}

pellets $(45 \mathrm{~g})$ in $300 \mathrm{~mL}$ of $50 \%$ methanol and vortexing for 1 minute; then the solution was left for 5 minutes at $100^{\circ} \mathrm{C}$, vortexed again for 1 minute, and left at $100^{\circ} \mathrm{C}$ in a water bath for 25 minutes). Methylation was done by adding $2 \mathrm{~mL}$ of solution ( $6 \mathrm{~N}$ hydrogen chloride in methanol) and then vortexed for 1 minute, followed by heating $\left(80^{\circ} \mathrm{C}\right)$ in a water bath. For extraction of fatty acids, $1.25 \mathrm{~mL}$ of solution $(25 \mathrm{~mL}$ methyl ter-butyl ether added to hexane) was added, and the solution was shaken for 10 minutes followed by removal of upper layer and addition of $3 \mathrm{~mL}$ of solution ( $10 \%$ sodium hydroxide in water while stirring). Finally, the top phase $(2 / 3)$ was removed and transferred into a gas chromatography vial and injected. Unsaturation index (UI) was calculated as (mol\% of each (poly)unsaturated fatty acid $\times$ number double bonds per each fatty acid)/100. 
2.3.2. Amino Acids. Powdered samples (0.1 g) were extracted with $2.5 \mathrm{~mL}$ followed by $1.5 \mathrm{~mL}$ and $1 \mathrm{~mL}$ of $70 \%$ aqueous methanol. After this, centrifugation was done for 10 minutes $(4000 \mathrm{rpm})$ at $4^{\circ} \mathrm{C}$. Supernatants were dissolved in aqueous methanol and the volume was made up to $5 \mathrm{~mL}$. It was now passed through Millipore filter $(0.45 \mu \mathrm{m})$. After this, samples $(10 \mu \mathrm{L})$ were dried using vacuum oven and, to these dried samples, $20 \mu \mathrm{L}$ derivatising agent (prepared by ethanol: triethylamine: water : phenylisothiocaynate) was mixed with it and redried it. Now the samples were left for 25 minutes at room temperature. Lastly, $1 \mathrm{~mL}$ ethanol was added and injected into UPLC (Waters India Pvt. Ltd.).

2.3.3. Tocopherol Composition. Tocopherol composition was estimated following standard method [25]. For this, samples were mixed with butylated hydroxytoluene (BHT) in hexane $(10 \mathrm{mg} / \mathrm{mL} ; 100 \mu \mu \mathrm{L})$ and IS solution in hexane $(\delta$ tocopherol; $1.6 \mu \mathrm{g} / \mathrm{mL} ; 250 \mu \mathrm{L}$ ). Thereafter, samples (500 mg) were vortexed for $1 \mathrm{~min}$ with methanol $(4 \mathrm{~mL})$. Then samples were again vortexed with hexane $(4 \mathrm{~mL})$. After this, $2 \mathrm{~mL}$ of saturated $\mathrm{NaCl}$ aqueous solution was added, and the mixture was vortexed $(1 \mathrm{~min})$, followed by centrifugation at $4000 \mathrm{~g}$ for $5 \mathrm{~min}$ and the upper layer was separated. The samples were again reextracted twice with hexane. The extracts were then vacuum-dried and redissolved in hexane $(1 \mathrm{~mL})$, followed by dehydration with anhydrous sodium sulphate, then filtered and transferred into a dark injection vial, and analysed by HPLC (Waters India Pvt. Ltd.). Chromatographic comparisons were made by authentic standards. Tocopherol contents in mushroom samples were expressed in $\mu \mathrm{g}$ per $\mathrm{g}$ of dry mushroom.

2.3.4. Evaluation of Other Bioactive Compounds. For $\beta$ carotene and lycopene estimation, dried powdered samples $(\sim 5 \mathrm{~g})$ were extracted with $100 \mathrm{~mL}$ of methanol at $25^{\circ} \mathrm{C}$ $(150 \mathrm{rpm})$ for 24 hours and filtered through Whatman Number 4 filter paper. The residue was again reextracted with 2 additional $100 \mathrm{~mL}$ portions of methanol. These extracts were evaporated to dryness at $42^{\circ} \mathrm{C}$, then redissolved in methanol at a concentration of $50 \mathrm{mg} / \mathrm{mL}$, and stored at $4^{\circ} \mathrm{C}$. The dried methanolic extract $(100 \mathrm{mg})$ was shaken vigorously with $10 \mathrm{~mL}$ of acetone/hexane mixture $(4: 6)$ for 1 minute and filtered. The absorbance of the filtrate was measured at 453 , 505 , and $663 \mathrm{~nm}$ [26]. $\beta$-carotene and lycopene content were estimated using the following equation:

$$
\begin{aligned}
\text { Lycopene }(\mathrm{mg} / 100 \mathrm{~mL}) \\
=(0.0458 \times A 663)+(0.372 \times A 505) \\
\quad-(0.0806 \times A 453) \beta \text {-carotene }(\mathrm{mg} / 100 \mathrm{~mL}) \\
=(0.216 \times A 663)-(0.304 \times A 505) \\
\quad+(0.452 \times A 453) .
\end{aligned}
$$

For phenolic compounds quantification, powdered samples $(1 \mathrm{~mL})$ were mixed with Folin and Ciocalteu's phenol reagent $(1 \mathrm{~mL})$. After 3 minutes, $1 \mathrm{~mL}$ of saturated sodium carbonate solution was added to the mixture, and the volume was adjusted to $10 \mathrm{~mL}$ with distilled water. The reaction was kept in the dark for 90 minutes, after which the absorbance was read at $725 \mathrm{~nm}$. Gallic acid was used to calculate the standard curve $\left(0.01-0.4 \mathrm{mM} ; R^{2}=0.9999\right)$ and the results were expressed as milligrams of gallic acid equivalents per gram of extract [27].

Total flavonoids of the sample extracts were measured by $\mathrm{AlCl}_{3}$ method [28]. For this, an aqueous extract $(1.5 \mathrm{~mL})$ was mixed with deionized distilled water $(5 \mathrm{~mL})$ and $0.3 \mathrm{~mL}$ of $5 \% \mathrm{NaNO}_{2}$. After five minutes of incubation at room temperature, $1.5 \mathrm{~mL}$ of $2 \%$ aluminium trichloride $\left(\mathrm{AlCl}_{3}\right)$ solution was added. After the next 6 minutes $2 \mathrm{~mL}$ of $1 \mathrm{M}$ $\mathrm{NaOH}$ was added. The mixture was vigorously shaken on orbital shaker for $5 \mathrm{~min}$ at $200 \mathrm{rpm}$ and the absorbance was read at $510 \mathrm{~nm}$ against a blank. Quercetin with different concentrations was used as a standard.

For ascorbic acid quantification, standard ascorbic acid solution ( $5 \mathrm{~mL}$ L-ascorbic acid in 3\% phosphoric acid) was added to $5 \mathrm{~mL}$ of phosphoric acid. A microburette was filled with dye, and the samples were titrated with the dye solution to a pink color, which persisted for 15 seconds. The dye factor (milligrams of ascorbic acid per milliliter of dye using formula: 0.5/titrate) was determined. A sample was prepared by taking $10 \mathrm{~g}$ of sample grounded in metaphosphoric acid, and the volume was increased up to $100 \mathrm{~mL}$. It was titrated after filtration until a pink color appeared [24]. The amount of ascorbic acid was calculated with the use of the following equation:

mg of ascorbic acid per100 $\mathrm{g}$ or $\mathrm{mL}$

$$
=\frac{\text { Titrate } \times \text { Dye factor } \times \text { Vol. made }}{\text { Aliquot of extract } \times \text { wt. of sample }} \times 100 \text {. }
$$

Anthocyanidins were quantified by using standard method [29]. Briefly, $0.5 \mathrm{~g}$ of samples was mixed with the solvent (mixture of 85:15 (v/v) of ethyl alcohol and hydrochloric acid $1.5 \mathrm{M}$ ) followed by ultrasonication for 15 minutes and filtration through Whatman filter paper number 1. Standard solution was prepared with cyaniding chloride with a concentration of $5-15 \mu \mathrm{g} / \mathrm{mL}$, in solvent which was used. The absorption was measured at $546 \mathrm{~nm}$. The total quantity of anthocyanins (expressed in $\mathrm{g}$ of cyaniding chloride $/ 100$ g extract $)=\left(A_{p} \times m_{\text {st }} \times f \times 100\right) /\left(A_{\text {st }} \times m_{p}\right)$, where $A_{p}$ is absorption rate of the sample solution; $m_{p}$ is mass of the processed sample, in $g ; A_{\text {st }}$ is absorption rate of the standard solution; $m_{\mathrm{st}}$ is mass of the processed standard solution, in $\mathrm{g}$; and $f$ is dilution coefficient.

2.4. Antioxidant Assays. DPPH scavenging activity was measured with adding DPPH $(200 \mu \mathrm{L})$ solution at different concentrations $(2-10 \mathrm{mg} / \mathrm{mL})$ to $0.05 \mathrm{~mL}$ of the samples (dissolved in ethanol). An equal amount of ethanol was added to the control. Ascorbic acid was used as the control [30]. The absorbance was read after $20 \mathrm{~min}$ at $517 \mathrm{~nm}$ and the inhibition was calculated using the formula

$$
\text { DPPH scavenging effect }(\%)=\frac{A_{0}-A_{P}}{A_{0}} \times 100 \text {, }
$$


where $A_{0}$ was the absorbance of the control and $A_{P}$ was the absorbance in the presence of the sample.

For ABTS radical scavenging activity $10 \mu \mathrm{L}$ of the sample was added to $4 \mathrm{~mL}$ of the diluted $\mathrm{ABTS}^{\circ+}$ solution (prepared by adding $7 \mathrm{mM}$ of the ABTS stock solution to $2.45 \mathrm{mM}$ potassium persulfate, kept in the dark, at room temperature, for $12-16 \mathrm{~h}$ before use). The solution was then diluted with $5 \mathrm{mM}$ phosphate-buffered saline ( $\mathrm{pH} 7.4)$ and absorbance was measured at $730 \mathrm{~nm}$ after $30 \mathrm{~min}$ [31]. The ABTS radical scavenging activity was calculated as

$$
S \%=\left(\frac{A_{\text {control }}-A_{\text {sample }}}{A_{\text {control }}}\right) \times 100 .
$$

For reducing power estimation, samples $(200 \mu \mathrm{L})$ were mixed with sodium phosphate buffer ( $\mathrm{pH} \mathrm{6.6),} 1 \mathrm{mM} \mathrm{FeSO}_{4}$, and $1 \%$ potassium ferricyanide and incubated for $20 \mathrm{~min}$ at $50^{\circ} \mathrm{C}$ after that trichloroacetic acid was added and the mixtures were centrifuged. Supernatant $(2.5 \mathrm{~mL})$ was mixed with an equal volume of water and $0.5 \mathrm{~mL} 0.1 \% \mathrm{FeCl}_{3}$. The absorbance was measured at $700 \mathrm{~nm}$ [32].

For $\mathrm{Fe}^{2+}$ chelating activity, $1 \mathrm{~mL}$ of the sample $(2-10 \mathrm{mg} /$ $\mathrm{mL}$ ) was mixed with $3.7 \mathrm{~mL}$ of ultrapure water, after that the mixture was reacted with ferrous chloride $(2 \mathrm{mmol} / \mathrm{L}$, $0.1 \mathrm{~mL})$ and ferrozine $(5 \mathrm{mmol} / \mathrm{L}, 0.2 \mathrm{~mL})$ for $20 \mathrm{~min}$ and the absorbance was read at $562 \mathrm{~nm}$ with using EDTA as control. The chelating activity was calculated using the formula

$$
\text { chelating activity }(\%)=\left[\frac{\left(A_{b}-A_{s}\right)}{A_{b}}\right] \times 100 \text {, }
$$

where $A_{b}$ is the absorbance of the blank and $A_{s}$ is the absorbance in the presence of the extract [33].

The scavenging activity of superoxide anion radicals was measured following standard method [34]. Samples (0$2.0 \mathrm{mg} / \mathrm{mL}, 1 \mathrm{~mL}$ ) and Tris- $\mathrm{HCl}$ buffer $(50.0 \mathrm{mM}, \mathrm{pH} 8.2$, $3 \mathrm{~mL}$ ) were incubated in a water bath at $25^{\circ} \mathrm{C}$ for $20 \mathrm{~min}$ and after this pyrogallic acid $(5.0 \mathrm{mM}, 0.4 \mathrm{~mL})$ was added. $\mathrm{HCl}$ solution $(8.0 \mathrm{M}, 0.1 \mathrm{~mL})$ was added to terminate the reaction after $4 \mathrm{~min}$. The absorbance of the mixture was measured at $320 \mathrm{~nm}$. The scavenging ability was calculated using the following formula:

$$
\text { scavenging ability }(\%)=\left(1-\frac{A_{\text {sample }}}{A_{\text {control }}}\right) \times 100 \text {, }
$$

where $A_{\text {control }}$ is the absorbance of control without the polysaccharide sample and $A_{\text {sample }}$ is the absorbance in the presence of the polysaccharide sample.

For ferric reducing antioxidant power (FRAP) assay, firstly, FRAP reagent was prepared by mixing TPTZ $(2.5 \mathrm{~mL}$, $10 \mathrm{mM}$ in $40 \mathrm{mM} \mathrm{HCl}$ ), $25 \mathrm{~mL}$ of $300 \mathrm{mM}$ acetate buffer, and $2.5 \mathrm{~mL}$ of $\mathrm{FeCl}_{3} \cdot 6 \mathrm{H}_{2} \mathrm{O}$. After this, freshly prepared FRAP reagent $(1.8 \mathrm{~mL})$ was taken in a test tube and incubated at $30^{\circ} \mathrm{C}$ in water bath for 10 minutes. Then, absorbance was read at $0 \mathrm{~min}\left(t_{0}\right)$. After this, $100 \mu \mathrm{L}$ of sample extract or standard and $100 \mu \mathrm{L}$ of distilled water were added to the test tube, mixed, and incubated at $30^{\circ} \mathrm{C}$ for 30 minutes. Then, the absorbance was taken at $593 \mathrm{~nm}\left(t_{30}\right)$. Ferrous sulphate was used as standard $[35,36]$. FRAP activity was determined against a standard curve of ferrous sulphate and the values were expressed as $\mu \mathrm{M} \mathrm{Fe}^{2+}$ equivalents per gram of extract and calculated using the following equation:

$$
\begin{aligned}
\text { FRAP value }= & \text { Absorbance }(\text { sample }+ \text { FRAP reagent }) \\
& - \text { Absorbance }(\text { FRAP reagent }) .
\end{aligned}
$$

2.5. Statistical Analysis. All experiments were performed 3 times and with 3 replicates. The results were analyzed using one-way analysis of variance (ANOVA). $p<0.05$ was considered significant, and SPSS software (SPSS Inc., Chicago, IL, USA) was used to calculate differences. Tukey-HSD at $p<0.05$ test was used to determine significant differences.

\section{Results}

3.1. Chemical Evaluation. Nutrient composition of the wild culinary mushrooms is shown in Table 2. Protein was found in high levels and varied between $5.16 \%$ in Inocybe splendens and $22.63 \%$ in Agaricus arvensis. Protein percentage in Pleurotus cystidiosus (20.69\%), Amanita caesarea (19.72\%), Agaricus campestris (18.38\%), Cantharellus cibarius (18.19\%), and Lentinus cladopus (18.59\%) was also found to be high. All the twenty culinary species were found to be low in fat content. Fat ranged from $0.10 \%$ in Laccaria laccata to $0.38 \%$ in Inocybe splendens. In general these wild culinary mushrooms consumed by local people were found to be higher in protein and low in fat although differences were observed in net value of individual species. Crude fibres ranged from $1.08 \%$ in Hygrocybe coccinea to $2.42 \%$ in Lentinus cladopus. Ash content varied between $0.11 \%$ in Inocybe splendens and $0.96 \%$ in Agaricus arvensis. Carbohydrates, calculated by difference, were also found to be in abundant amounts and their percentage was ranged from $31.19 \%$ in Inocybe splendens to $57.12 \%$ in Agaricus arvensis. Nutrient contents of Inocybe splendens, Hygrocybe nivea, and Conocybe tenera were found to be less as compared to other species.

There are several reports about the toxicity reports due to mushrooms on humans in these areas and hence preliminary studies were done to check the toxicity level of mushrooms. For all the twenty species being used by the people for culinary purposes the test was found to be negative. That means these species are nontoxic and hence recommended for consumption.

All the culinary mushroom species contained glucose and rhamnose as the principal carbohydrates (Table 3). Nevertheless, the present study also describes the presence of xylose and mannose in all the studied species. However, galactose and fructose were detected in very low percentage in some of the species. Russula mairei contained lowest percentage of glucose (21.60\%) and Agaricus arvensis contained highest percentage of glucose $(64.12 \%)$.

3.2. Bioactive Evaluation. The results of fatty acid composition (total saturated fatty acids SFA, monounsaturated fatty acids MUFA, and polyunsaturated fatty acids PUFA) of all the species are shown in Table 4. In general, the major fatty 
TABle 2: Percent chemical composition of twenty wild culinary mushroom species collected from northern Himalayan regions.

\begin{tabular}{|c|c|c|c|c|c|}
\hline Species & Protein & Crude fat & Fibres & Ash & Carbohydrates \\
\hline Agaricus arvensis & $22.63 \pm 0.2^{1}$ & $0.22 \pm 0.0^{\mathrm{a}}$ & $2.11 \pm 0.0^{\mathrm{c}}$ & $0.96 \pm 0.0^{\mathrm{a}}$ & $57.12 \pm 2.7^{\mathrm{m}}$ \\
\hline A. campestris & $18.38 \pm 0.6^{\mathrm{j}}$ & $0.12 \pm 0.0^{\mathrm{a}}$ & $1.17 \pm 0.0^{\mathrm{b}}$ & $0.87 \pm 0.0^{\mathrm{a}}$ & $43.45 \pm 2.4^{\mathrm{j}}$ \\
\hline A. comtulus & $12.85 \pm 0.2^{\mathrm{f}}$ & $0.20 \pm 0.0^{\mathrm{a}}$ & $1.93 \pm 0.0^{\mathrm{b}}$ & $0.30 \pm 0.0^{\mathrm{a}}$ & $39.28 \pm 3.8^{\mathrm{i}}$ \\
\hline A. silvicola & $17.14 \pm 0.1^{\mathrm{i}}$ & $0.26 \pm 0.0^{\mathrm{a}}$ & $1.82 \pm 0.0^{\mathrm{b}}$ & $0.54 \pm 0.0^{\mathrm{a}}$ & $48.53 \pm 3.2^{\mathrm{k}}$ \\
\hline Amanita caesarea & $19.72 \pm 0.3^{\mathrm{h}}$ & $0.21 \pm 0.0^{\mathrm{a}}$ & $1.18 \pm 0.0^{\mathrm{b}}$ & $0.42 \pm 0.0^{\mathrm{a}}$ & $42.16 \pm 1.9^{1}$ \\
\hline A. citrine & $11.12 \pm 0.1^{\mathrm{e}}$ & $0.17 \pm 0.0^{\mathrm{a}}$ & $1.62 \pm 0.0^{\mathrm{b}}$ & $0.40 \pm 0.0^{\mathrm{a}}$ & $27.15 \pm 3.2^{\mathrm{a}}$ \\
\hline A. fulva & $10.11 \pm 0.1^{\mathrm{d}}$ & $0.22 \pm 0.0^{\mathrm{a}}$ & $1.83 \pm 0.0^{\mathrm{b}}$ & $0.11 \pm 0.0^{\mathrm{a}}$ & $32.12 \pm 2.3^{\mathrm{d}}$ \\
\hline Cantharellus cibarius & $18.19 \pm 0.5^{j}$ & $0.27 \pm 0.0^{\mathrm{a}}$ & $2.08 \pm 0.0^{c}$ & $0.55 \pm 0.0^{\mathrm{a}}$ & $56.42 \pm 2.9^{\mathrm{m}}$ \\
\hline Conocybe tenera & $8.61 \pm 0.3^{c}$ & $0.25 \pm 0.0^{\mathrm{a}}$ & $0.91 \pm 0.0^{\mathrm{a}}$ & $0.26 \pm 0.0^{\mathrm{a}}$ & $37.10 \pm 3.7^{\mathrm{h}}$ \\
\hline Gymnopilus junonius & $14.23 \pm 0.1^{\mathrm{g}}$ & $0.23 \pm 0.0^{\mathrm{a}}$ & $1.23 \pm 0.0^{\mathrm{b}}$ & $0.41 \pm 0.0^{\mathrm{a}}$ & $49.29 \pm 7.3^{\mathrm{k}}$ \\
\hline Hygrocybe coccinea & $12.15 \pm 0.6^{\mathrm{f}}$ & $0.34 \pm 0.0^{\mathrm{a}}$ & $1.08 \pm 0.0^{\mathrm{b}}$ & $0.20 \pm 0.0^{\mathrm{a}}$ & $36.44 \pm 2.3^{g}$ \\
\hline Hygrocybe nivea & $7.60 \pm 0.2^{\mathrm{b}}$ & $0.26 \pm 0.0^{\mathrm{a}}$ & $1.14 \pm 0.0^{\mathrm{b}}$ & $0.16 \pm 0.0^{\mathrm{a}}$ & $32.14 \pm 2.3^{\mathrm{d}}$ \\
\hline Inocybe splendens & $5.16 \pm 0.4^{\mathrm{a}}$ & $0.38 \pm 0.0^{\mathrm{a}}$ & $0.85 \pm 0.0^{\mathrm{a}}$ & $0.11 \pm 0.0^{\mathrm{a}}$ & $31.19 \pm 2.5^{\mathrm{c}}$ \\
\hline Lactarius pubescens & $15.12 \pm 0.7^{\mathrm{h}}$ & $0.24 \pm 0.0^{\mathrm{a}}$ & $1.98 \pm 0.0^{\mathrm{b}}$ & $0.44 \pm 0.0^{\mathrm{a}}$ & $32.40 \pm 2.0^{\mathrm{d}}$ \\
\hline Laccaria laccata & $10.14 \pm 0.4^{\mathrm{d}}$ & $0.10 \pm 0.0^{\mathrm{a}}$ & $1.95 \pm 0.0^{\mathrm{b}}$ & $0.36 \pm 0.0^{\mathrm{a}}$ & $30.18 \pm 4.2^{\mathrm{b}}$ \\
\hline Lepista nuda & $10.18 \pm 0.7^{\mathrm{d}}$ & $0.25 \pm 0.0^{\mathrm{a}}$ & $1.26 \pm 0.0^{\mathrm{b}}$ & $0.21 \pm 0.0^{\mathrm{a}}$ & $33.13 \pm 5.2^{\mathrm{e}}$ \\
\hline Lentinus cladopus & $18.59 \pm 0.9^{j}$ & $0.24 \pm 0.0^{\mathrm{a}}$ & $2.42 \pm 0.0^{\mathrm{c}}$ & $0.49 \pm 0.0^{\mathrm{a}}$ & $56.49 \pm 2.1^{1}$ \\
\hline Pleurotus cystidiosus & $20.69 \pm 0.3^{\mathrm{k}}$ & $0.20 \pm 0.0^{\mathrm{a}}$ & $2.16 \pm 0.0^{c}$ & $0.42 \pm 0.0^{\mathrm{a}}$ & $52.20 \pm 3.6^{\mathrm{n}}$ \\
\hline Russula lepida & $12.10 \pm 0.4^{\mathrm{f}}$ & $0.28 \pm 0.0^{\mathrm{a}}$ & $1.19 \pm 0.0^{\mathrm{b}}$ & $0.17 \pm 0.0^{\mathrm{a}}$ & $34.15 \pm 4.3^{\mathrm{f}}$ \\
\hline R. mairei & $11.03 \pm 0.9^{\mathrm{e}}$ & $0.22 \pm 0.0^{\mathrm{a}}$ & $1.38 \pm 0.0^{\mathrm{b}}$ & $0.13 \pm 0.0^{\mathrm{a}}$ & $36.40 \pm 3.1^{\mathrm{g}}$ \\
\hline
\end{tabular}

Values are expressed as mean \pm SE and different letters represent the significant difference in each column with $p \leq 0.05$ according to Tukey's test.

TABLE 3: Percent monosaccharide composition of twenty species collected from northern Himalayan regions showing richness in glucose, rhamnose, mannose, xylose, and galactose and fructose in lower percentage.

\begin{tabular}{|c|c|c|c|c|c|c|}
\hline Species & Xylose & Glucose & Rhamnose & Mannose & Galactose & Fructose \\
\hline Agaricus arvensis & $10.17 \pm 0.3^{g}$ & $64.12 \pm 2.7^{\circ}$ & $22.10 \pm 2.7^{\mathrm{k}}$ & $4.15 \pm 0.7^{\mathrm{e}}$ & $0.9 \pm 0.0^{\mathrm{b}}$ & $0.06 \pm 0.0^{\mathrm{a}}$ \\
\hline A. campestris & $5.20 \pm 0.2^{\mathrm{d}}$ & $48.63 \pm 2.2^{\mathrm{k}}$ & $17.19 \pm 1.5^{\mathrm{h}}$ & $3.10 \pm 0.2^{\mathrm{d}}$ & $0.7 \pm 0.0^{\mathrm{b}}$ & $0.02 \pm 0.0^{\mathrm{a}}$ \\
\hline A. comtulus & $4.21 \pm 0.5^{\mathrm{c}}$ & $35.10 \pm 3.0^{\mathrm{g}}$ & $10.18 \pm 1.7^{\mathrm{b}}$ & $2.32 \pm 0.2^{\mathrm{c}}$ & $0.1 \pm 0.0^{\mathrm{b}}$ & $0.05 \pm 0.0^{\mathrm{a}}$ \\
\hline A. silvicola & $6.46 \pm 0.1^{\mathrm{e}}$ & $44.12 \pm 3.7^{j}$ & $14.29 \pm 1.5^{\mathrm{f}}$ & $3.19 \pm 0.6^{\mathrm{d}}$ & $0.2 \pm 0.0^{\mathrm{b}}$ & $0.06 \pm 0.0^{\mathrm{a}}$ \\
\hline Amanita caesarea & $12.15 \pm 0.4^{\mathrm{h}}$ & $53.60 \pm 2.6^{\mathrm{r}}$ & $23.17 \pm 1.2^{1}$ & $5.31 \pm 0.6^{\mathrm{f}}$ & $0.7 \pm 0.0^{\mathrm{b}}$ & $0.01 \pm 0.0^{\mathrm{a}}$ \\
\hline A. citrine & $4.16 \pm 0.1^{\mathrm{c}}$ & $28.60 \pm 2.1^{\mathrm{d}}$ & $12.81 \pm 1.6^{j}$ & $1.12 \pm 0.0^{\mathrm{b}}$ & $0.3 \pm 0.0^{\mathrm{b}}$ & ND \\
\hline A. fulva & $6.21 \pm 0.2^{\mathrm{e}}$ & $32.15 \pm 2.9^{f}$ & $14.25 \pm 1.7^{\mathrm{f}}$ & $2.80 \pm 0.5^{\mathrm{c}}$ & $0.2 \pm 0.0^{\mathrm{b}}$ & ND \\
\hline Cantharellus cibarius & $13.27 \pm 0.5^{\mathrm{i}}$ & $59.72 \pm 3.4^{\mathrm{m}}$ & $22.17 \pm 2.3^{\mathrm{k}}$ & $4.98 \pm 0.7^{\mathrm{e}}$ & $0.8 \pm 0.0^{\mathrm{b}}$ & $0.06 \pm 0.0^{\mathrm{a}}$ \\
\hline Conocybe tenera & $2.25 \pm 0.1^{\mathrm{a}}$ & $38.67 \pm 2.8^{\mathrm{h}}$ & $10.29 \pm 3.5^{\mathrm{a}}$ & $1.13 \pm 0.0^{\mathrm{b}}$ & ND & ND \\
\hline Gymnopilus junonius & $8.21 \pm 0.5^{\mathrm{h}}$ & $55.16 \pm 3.4^{1}$ & $16.18 \pm 2.1^{\mathrm{g}}$ & $2.32 \pm 0.2^{c}$ & $0.5 \pm 0.0^{\mathrm{b}}$ & $0.05 \pm 0.0^{\mathrm{a}}$ \\
\hline Hygrocybe coccinea & $3.16 \pm 0.1^{\mathrm{b}}$ & $29.16 \pm 3.7^{\mathrm{e}}$ & $11.12 \pm 1.5^{\mathrm{c}}$ & $1.10 \pm 0.6^{\mathrm{b}}$ & $\mathrm{ND}$ & ND \\
\hline H. nivea & $3.15 \pm 0.0^{\mathrm{b}}$ & $22.61 \pm 2.6^{b}$ & $13.16 \pm 1.2^{\mathrm{e}}$ & $1.30 \pm 0.6^{\mathrm{b}}$ & $\mathrm{ND}$ & ND \\
\hline Inocybe splendens & $4.29 \pm 0.2^{c}$ & $28.62 \pm 2.5^{\mathrm{d}}$ & $9.81 \pm 1.6^{\mathrm{a}}$ & $0.98 \pm 0.0^{\mathrm{a}}$ & ND & ND \\
\hline Lactarius pubescens & $5.28 \pm 0.3^{\mathrm{d}}$ & $32.15 \pm 2.2^{\mathrm{f}}$ & $12.25 \pm 2.0^{\mathrm{d}}$ & $2.84 \pm 0.7^{\mathrm{c}}$ & $0.7 \pm 0.0^{\mathrm{b}}$ & $0.02 \pm 0.0^{\mathrm{a}}$ \\
\hline Laccaria laccata & $5.23 \pm 0.5^{\mathrm{d}}$ & $24.12 \pm 4.5^{\mathrm{c}}$ & $12.19 \pm 2.1^{\mathrm{d}}$ & $1.98 \pm 0.5^{\mathrm{b}}$ & $0.2 \pm 0.0^{\mathrm{b}}$ & $0.01 \pm 0.0^{\mathrm{a}}$ \\
\hline Lepista nuda & $2.10 \pm 0.1^{\mathrm{a}}$ & $40.61 \pm 2.7^{\mathrm{i}}$ & $10.19 \pm 1.5^{\mathrm{b}}$ & $2.10 \pm 0.0^{\mathrm{c}}$ & $\mathrm{ND}$ & ND \\
\hline Lentinus cladopus & $9.21 \pm 0.5^{\mathrm{f}}$ & $61.19 \pm 3.0^{\mathrm{n}}$ & $21.18 \pm 1.3^{\mathrm{j}}$ & $3.32 \pm 0.2^{\mathrm{d}}$ & $0.6 \pm 0.0^{\mathrm{b}}$ & $0.05 \pm 0.0^{\mathrm{a}}$ \\
\hline Pleurotus cystidiosus & $10.79 \pm 0.6^{\mathrm{g}}$ & $59.11 \pm 2.7^{\mathrm{m}}$ & $19.12 \pm 1.5^{\mathrm{i}}$ & $4.10 \pm 0.6^{\mathrm{e}}$ & $0.6 \pm 0.0^{\mathrm{b}}$ & $0.04 \pm 0.0^{\mathrm{a}}$ \\
\hline Russula lepida & $5.15 \pm 0.1^{\mathrm{d}}$ & $32.61 \pm 3.6^{\mathrm{f}}$ & $13.16 \pm 1.2^{\mathrm{e}}$ & $2.31 \pm 0.1^{c}$ & ND & ND \\
\hline R. mairei & $4.26 \pm 0.1^{c}$ & $21.60 \pm 2.1^{\mathrm{a}}$ & $12.81 \pm 1.6^{\mathrm{d}}$ & $2.12 \pm 0.0^{\mathrm{c}}$ & ND & ND \\
\hline
\end{tabular}

$\mathrm{ND}=$ not detected .

Values are expressed as mean \pm SE and different letters represent the significant difference in each column with $p \leq 0.05$ according to Tukey's test. 


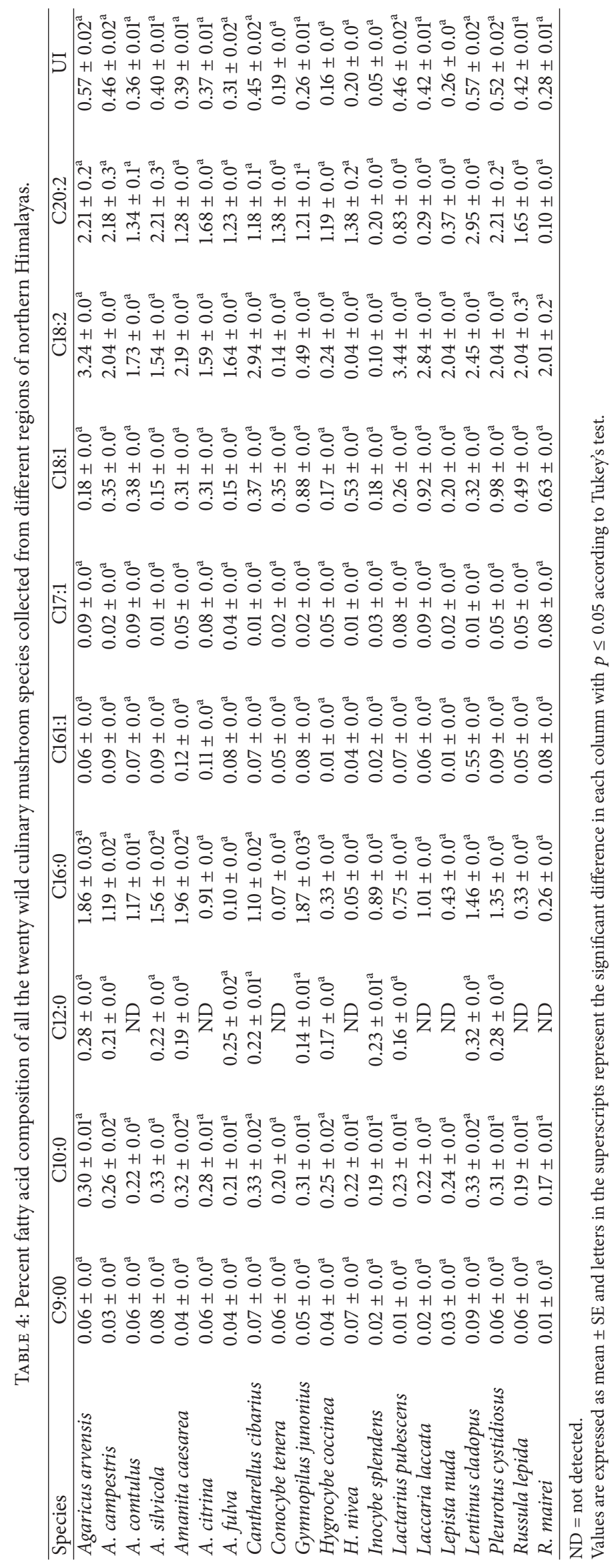


TABle 5: Percent amino acids composition of all the wild culinary species collected from northern Himalayas.

\begin{tabular}{|c|c|c|c|c|c|}
\hline Species & Aspartic acid & Arginine & Alanine & Proline & Tyrosine \\
\hline Agaricus arvensis & $0.38 \pm 0.0^{\mathrm{a}}$ & $0.27 \pm 0.0^{\mathrm{a}}$ & $0.14 \pm 0.0^{\mathrm{a}}$ & $0.06 \pm 0.0^{\mathrm{a}}$ & $0.19 \pm 0.0^{\mathrm{a}}$ \\
\hline A. campestris & $0.30 \pm 0.0^{\mathrm{a}}$ & $0.19 \pm 0.0^{\mathrm{a}}$ & $0.10 \pm 0.0^{\mathrm{a}}$ & $0.02 \pm 0.0^{\mathrm{a}}$ & $0.14 \pm 0.0^{\mathrm{a}}$ \\
\hline A. comtulus & $0.27 \pm 0.0^{\mathrm{a}}$ & $0.15 \pm 0.0^{\mathrm{a}}$ & $0.10 \pm 0.0^{\mathrm{a}}$ & $0.02 \pm 0.0^{\mathrm{a}}$ & $0.12 \pm 0.0^{\mathrm{a}}$ \\
\hline A. silvicola & $0.29 \pm 0.0^{\mathrm{a}}$ & $0.23 \pm 0.0^{\mathrm{a}}$ & $0.08 \pm 0.0^{\mathrm{a}}$ & $0.03 \pm 0.0^{\mathrm{a}}$ & $0.17 \pm 0.0^{\mathrm{a}}$ \\
\hline Amanita caesarea & $0.39 \pm 0.0^{\mathrm{a}}$ & $0.25 \pm 0.0^{\mathrm{a}}$ & $0.13 \pm 0.0^{\mathrm{a}}$ & $0.07 \pm 0.0^{\mathrm{a}}$ & $0.21 \pm 0.0^{\mathrm{a}}$ \\
\hline A. citrina & $0.21 \pm 0.0^{\mathrm{a}}$ & $0.20 \pm 0.0^{\mathrm{a}}$ & $0.11 \pm 0.0^{\mathrm{a}}$ & $0.04 \pm 0.0^{\mathrm{a}}$ & $0.15 \pm 0.0^{\mathrm{a}}$ \\
\hline A. fulva & $0.33 \pm 0.0^{\mathrm{a}}$ & $0.17 \pm 0.0^{\mathrm{a}}$ & $0.07 \pm 0.0^{\mathrm{a}}$ & $0.03 \pm 0.0^{\mathrm{a}}$ & $0.16 \pm 0.0^{\mathrm{a}}$ \\
\hline Cantharellus cibarius & $0.20 \pm 0.0^{\mathrm{a}}$ & $0.29 \pm 0.0^{\mathrm{a}}$ & $0.13 \pm 0.0^{\mathrm{a}}$ & $0.06 \pm 0.0^{\mathrm{a}}$ & $0.20 \pm 0.0^{\mathrm{a}}$ \\
\hline Conocybe tenera & $0.31 \pm 0.0^{\mathrm{a}}$ & $0.21 \pm 0.0^{\mathrm{a}}$ & $0.06 \pm 0.0^{\mathrm{a}}$ & $0.01 \pm 0.0^{\mathrm{a}}$ & $0.10 \pm 0.0^{\mathrm{a}}$ \\
\hline Gymnopilus junonius & $0.25 \pm 0.0^{\mathrm{a}}$ & $0.25 \pm 0.0^{\mathrm{a}}$ & $0.14 \pm 0.0^{\mathrm{a}}$ & $0.05 \pm 0.0^{\mathrm{a}}$ & $0.17 \pm 0.0^{\mathrm{a}}$ \\
\hline Hygrocybe coccinea & $0.22 \pm 0.0^{\mathrm{a}}$ & $0.12 \pm 0.0^{\mathrm{a}}$ & $0.04 \pm 0.0^{\mathrm{a}}$ & $0.01 \pm 0.0^{\mathrm{a}}$ & $0.11 \pm 0.0^{\mathrm{a}}$ \\
\hline H. nivea & $0.19 \pm 0.0^{\mathrm{a}}$ & $0.13 \pm 0.0^{\mathrm{a}}$ & $0.04 \pm 0.0^{\mathrm{a}}$ & $0.01 \pm 0.0^{\mathrm{a}}$ & $0.11 \pm 0.0^{\mathrm{a}}$ \\
\hline Inocybe splendens & $0.23 \pm 0.0^{\mathrm{a}}$ & $0.20 \pm 0.0^{\mathrm{a}}$ & $0.08 \pm 0.0^{\mathrm{a}}$ & $0.04 \pm 0.0^{\mathrm{a}}$ & $0.14 \pm 0.0^{\mathrm{a}}$ \\
\hline Lactarius pubescens & $0.22 \pm 0.0^{\mathrm{a}}$ & $0.23 \pm 0.0^{\mathrm{a}}$ & $0.10 \pm 0.0^{\mathrm{a}}$ & $0.04 \pm 0.0^{\mathrm{a}}$ & $0.15 \pm 0.0^{\mathrm{a}}$ \\
\hline Laccaria laccata & $0.24 \pm 0.0^{\mathrm{a}}$ & $0.22 \pm 0.0^{\mathrm{a}}$ & $0.08 \pm 0.0^{\mathrm{a}}$ & $0.01 \pm 0.0^{\mathrm{a}}$ & $0.13 \pm 0.0^{\mathrm{a}}$ \\
\hline Lepista nuda & $0.33 \pm 0.0^{\mathrm{a}}$ & $0.21 \pm 0.0^{\mathrm{a}}$ & $0.06 \pm 0.0^{\mathrm{a}}$ & $0.01 \pm 0.0^{\mathrm{a}}$ & $0.12 \pm 0.0^{\mathrm{a}}$ \\
\hline Lentinus cladopus & $0.36 \pm 0.0^{\mathrm{a}}$ & $0.29 \pm 0.0^{\mathrm{a}}$ & $0.13 \pm 0.0^{\mathrm{a}}$ & $0.05 \pm 0.0^{\mathrm{a}}$ & $0.18 \pm 0.0^{\mathrm{a}}$ \\
\hline Pleurotus cystidiosus & $0.35 \pm 0.0^{\mathrm{a}}$ & $0.27 \pm 0.0^{\mathrm{a}}$ & $0.12 \pm 0.0^{\mathrm{a}}$ & $0.04 \pm 0.0^{\mathrm{a}}$ & $0.20 \pm 0.0^{\mathrm{a}}$ \\
\hline Russula lepida & $0.21 \pm 0.0^{\mathrm{a}}$ & $0.20 \pm 0.0^{\mathrm{a}}$ & $0.06 \pm 0.0^{\mathrm{a}}$ & $0.02 \pm 0.0^{\mathrm{a}}$ & $0.12 \pm 0.0^{\mathrm{a}}$ \\
\hline R. mairei & $0.20 \pm 0.0^{\mathrm{a}}$ & $0.19 \pm 0.0^{\mathrm{a}}$ & $0.06 \pm 0.0^{\mathrm{a}}$ & $0.01 \pm 0.0^{\mathrm{a}}$ & $0.11 \pm 0.0^{\mathrm{a}}$ \\
\hline
\end{tabular}

Values are expressed as mean \pm SE and letters in superscript represent the significant difference in each column with $p \leq 0.05$ according to Tukey's test.

acids found in the studied species were linoleic acid (C18:2), followed by oleic acid (C18:1) and palmitic acid (C16:0). Besides these three main fatty acids already described, six more were identified and quantified. PUFA were the main group of fatty acids documented in all the species. Agaricus arvensis, Amanita caesarea, Cantharellus cibarius, Lentinus cladopus, and Pleurotus cystidiosus contained lower value of MUFA but higher percentage of PUFA as compared to other species due to the higher percentage of linoleic acid. However, UFA predominated over SFA in all the studied species ranging from 65 to $70 \%$.

Amino acid composition of all the species is shown in Table 5. In all the species aspartic acid (0.19-0.39\%) was found to be predominated amino acid followed by tyrosine (0.10-0.21\%), arginine (0.12-0.29\%), alanine (0.04-0.14\%), and proline (0.01-0.07\%). Amanita caesarea, Agaricus arvensis, Cantharellus cibarius, Lentinus cladopus, and Pleurotus cystidiosus contained maximum amount of these amino acids. Tocopherol contents in all the studied mushroom species including three wild are detailed in Table 6. $\alpha$ tocopherol and $\beta$-tocopherol were found to be present in all the species. However, $\gamma$-tocopherol was documented from few species only. Tocopherol content was ranged from 0.90 to $4.33 \mu \mathrm{g} / \mathrm{g}$ in all the species. Cantharellus cibarius $(4.33 \pm$ $0.0 \mu \mathrm{g} / \mathrm{g}$ ) contained all the three isomers in higher amount as compared to other species. $\beta$-tocopherol was found in higher amounts as compared to $\alpha$-tocopherol. $\gamma$-tocopherol was detected only in nine species. Cantharellus cibarius (4.33 \pm $0.0 \mu \mathrm{g} / \mathrm{g}$ ) contained higher amounts of $\gamma$ tocopherol.

Results obtained for $\beta$-carotene, lycopene, flavonoids, ascorbic acid, and anthocyanidins composition of all the twenty species are presented in Table 7. Phenols were the major antioxidant component detected in significant amounts from all the species $(19.12-63.36 \mathrm{mg} / \mathrm{g})$, followed by anthocyanidins (6.14-14.25 mg cyanidin chloride/100 g extract), flavonoids (1.14-4.17 mg/g) ascorbic acid which was found in small amounts $(0.20-0.99 \mathrm{mg} / \mathrm{g}), \beta$-carotene $(0.21-0.79 \mu \mathrm{g} / 100 \mathrm{~g})$, and lycopene $(0.19-0.38 \mu \mathrm{g} / 100 \mathrm{~g})$. Each species differed with other species in net amounts of all these components. Species like Agaricus arvensis, Amanita caesarea, Gymnopilus junonius, Lentinus cladopus, and Pleurotus cystidiosus contained higher values of these components as compared to other species.

3.3. Antioxidant Evaluation. Antioxidant properties of all the species were expressed as $\mathrm{EC}_{50}$ values for comparison (Table 8). Higher $\mathrm{EC}_{50}$ values indicate lower effectiveness in antioxidant properties. $\mathrm{EC}_{50}$ values obtained for $\mathrm{DPPH}$ radical scavenging activity in all the species showed differences in effectiveness in antioxidant properties. Among all the species Cantharellus cibarius showed lowest $\mathrm{EC}_{50}$ values $(1.76 \pm 0.2 \mathrm{mg} / \mathrm{mL})$ followed by Amanita caesarea $(2.02 \pm$ $0.2 \mathrm{mg} / \mathrm{mL})$ and Agaricus arvensis $(2.12 \pm 0.4 \mathrm{mg} / \mathrm{mL})$. Other species showed slightly higher $\mathrm{EC}_{50}$ values and therefore lesser DPPH radical scavenging activity. Cantharellus cibarius showed higher DPPH radical scavenging activity and Inocybe splendens showed lower DPPH radical scavenging activity than other species.

For ABTS radical scavenging activities $\mathrm{EC}_{50}$ ranged from 4.26 to $1.45 \mathrm{mg} / \mathrm{mL}$. Lowest $\mathrm{EC}_{50}$ values were obtained for Amanita caesarea $(1.45 \pm 0.6 \mathrm{mg} / \mathrm{mL})$ showing high antioxidant activities of this species. Higher $\mathrm{EC}_{50}$ values were 
TABLE 6: Tocopherol composition $(\mu \mathrm{g} / \mathrm{g})$ of twenty species collected from northern Himalayan regions.

\begin{tabular}{|c|c|c|c|c|}
\hline Species & $\alpha$-tocopherol & $\beta$-tocopherol & $\gamma$-tocopherol & Total \\
\hline Agaricus arvensis & $0.65 \pm 0.0^{\mathrm{a}}$ & $1.24 \pm 0.0^{\mathrm{b}}$ & $1.12 \pm 0.0^{\mathrm{b}}$ & $3.01 \pm 0.0^{\mathrm{d}}$ \\
\hline A. campestris & $0.62 \pm 0.0^{\mathrm{a}}$ & $1.20 \pm 0.0^{\mathrm{b}}$ & $1.10 \pm 0.0^{\mathrm{b}}$ & $2.92 \pm 0.0^{c}$ \\
\hline A. comtulus & $0.55 \pm 0.0^{\mathrm{a}}$ & $0.96 \pm 0.0^{\mathrm{a}}$ & ND & $1.51 \pm 0.0^{\mathrm{b}}$ \\
\hline A. silvicola & $0.75 \pm 0.0^{\mathrm{a}}$ & $0.87 \pm 0.0^{\mathrm{a}}$ & $0.98 \pm 0.0^{\mathrm{a}}$ & $2.60 \pm 0.0^{c}$ \\
\hline Amanita caesarea & $0.95 \pm 0.0^{\mathrm{a}}$ & $1.56 \pm 0.0^{\mathrm{b}}$ & $1.22 \pm 0.0^{\mathrm{b}}$ & $3.73 \pm 0.0^{\mathrm{d}}$ \\
\hline A. citrina & $0.43 \pm 0.0^{\mathrm{a}}$ & $1.16 \pm 0.0^{\mathrm{b}}$ & ND & $1.59 \pm 0.0^{\mathrm{b}}$ \\
\hline A. fulva & $0.41 \pm 0.0^{\mathrm{a}}$ & $1.42 \pm 0.0^{\mathrm{b}}$ & ND & $1.83 \pm 0.0^{\mathrm{b}}$ \\
\hline Cantharellus cibarius & $1.25 \pm 0.0^{\mathrm{b}}$ & $1.79 \pm 0.0^{\mathrm{b}}$ & $1.29 \pm 0.0^{b}$ & $4.33 \pm 0.0^{\mathrm{e}}$ \\
\hline Conocybe tenera & $0.25 \pm 0.0^{\mathrm{a}}$ & $0.86 \pm 0.0^{\mathrm{a}}$ & ND & $1.11 \pm 0.0^{\mathrm{b}}$ \\
\hline Gymnopilus junonius & $0.83 \pm 0.0^{\mathrm{a}}$ & $1.56 \pm 0.0^{\mathrm{b}}$ & $1.17 \pm 0.0^{\mathrm{b}}$ & $3.56 \pm 0.0^{\mathrm{d}}$ \\
\hline Hygrocybe coccinea & $0.46 \pm 0.0^{\mathrm{a}}$ & $0.72 \pm 0.0^{\mathrm{a}}$ & ND & $1.18 \pm 0.0^{\mathrm{b}}$ \\
\hline H. nivea & $0.41 \pm 0.0^{\mathrm{a}}$ & $0.70 \pm 0.0^{\mathrm{a}}$ & ND & $1.11 \pm 0.0^{\mathrm{b}}$ \\
\hline Inocybe splendens & $0.25 \pm 0.0^{\mathrm{a}}$ & $0.52 \pm 0.0^{\mathrm{a}}$ & ND & $0.77 \pm 0.0^{\mathrm{a}}$ \\
\hline Lactarius pubescens & $0.66 \pm 0.0^{\mathrm{a}}$ & $1.02 \pm 0.0^{b}$ & $0.92 \pm 0.0^{\mathrm{a}}$ & $2.60 \pm 0.0^{c}$ \\
\hline Laccaria laccata & $0.35 \pm 0.0^{\mathrm{a}}$ & $1.17 \pm 0.0^{b}$ & ND & $1.52 \pm 0.0^{\mathrm{b}}$ \\
\hline Lepista nuda & $0.21 \pm 0.0^{\mathrm{a}}$ & $0.93 \pm 0.0^{\mathrm{a}}$ & ND & $1.14 \pm 0.0^{\mathrm{b}}$ \\
\hline Lentinus cladopus & $0.85 \pm 0.0^{\mathrm{a}}$ & $1.51 \pm 0.0^{\mathrm{b}}$ & $1.19 \pm 0.0^{\mathrm{b}}$ & $3.55 \pm 0.0^{\mathrm{d}}$ \\
\hline Pleurotus cystidiosus & $1.15 \pm 0.0^{\mathrm{b}}$ & $1.62 \pm 0.0^{\mathrm{b}}$ & $1.16 \pm 0.0^{b}$ & $3.93 \pm 0.0^{\mathrm{d}}$ \\
\hline Russula lepida & $0.32 \pm 0.0^{\mathrm{a}}$ & $0.65 \pm 0.0^{\mathrm{a}}$ & ND & $0.97 \pm 0.0^{\mathrm{a}}$ \\
\hline R. mairei & $0.31 \pm 0.0^{\mathrm{a}}$ & $0.59 \pm 0.0^{\mathrm{a}}$ & ND & $0.90 \pm 0.0^{\mathrm{a}}$ \\
\hline
\end{tabular}

$\mathrm{ND}=$ not detected.

Values are expressed as mean \pm SE and different letters represent the significant difference in each column with $p \leq 0.05$ according to Tukey's test.

TABLE 7: Other bioactive compounds evaluated from all the species.

\begin{tabular}{|c|c|c|c|c|c|c|}
\hline Species & $\begin{array}{c}\beta \text {-carotene } \\
(\mu \mathrm{g} / 100 \mathrm{~g})\end{array}$ & $\begin{array}{l}\text { Lycopene } \\
(\mu \mathrm{g} / 100 \mathrm{~g})\end{array}$ & $\begin{array}{c}\text { Phenolic } \\
\text { compounds } \\
\text { (mg/100 g of gallic } \\
\text { acid) }\end{array}$ & $\begin{array}{c}\text { Flavonoids } \\
\text { (mg gallic acid } \\
\text { equivalents/g) }\end{array}$ & $\begin{array}{l}\text { Ascorbic acid } \\
(\mathrm{mg} / 100 \mathrm{~g})\end{array}$ & $\begin{array}{c}\text { Anthocyanidins } \\
\text { (mg cyanidin } \\
\text { chloride/100g } \\
\text { extract) }\end{array}$ \\
\hline Agaricus arvensis & $0.75 \pm 0.0^{\mathrm{a}}$ & $0.38 \pm 0.0^{\mathrm{a}}$ & $55.13 \pm 2.1^{\mathrm{i}}$ & $2.70 \pm 0.0^{\mathrm{b}}$ & $0.85 \pm 0.0^{\mathrm{a}}$ & $12.19 \pm 0.2^{\mathrm{f}}$ \\
\hline A. campestris & $0.50 \pm 0.0^{\mathrm{a}}$ & $0.27 \pm 0.0^{\mathrm{a}}$ & $43.17 \pm 1.7^{\mathrm{h}}$ & $2.25 \pm 0.0^{\mathrm{b}}$ & $0.50 \pm 0.0^{\mathrm{a}}$ & $10.26 \pm 0.3^{\mathrm{d}}$ \\
\hline A. comtulus & $0.70 \pm 0.0^{\mathrm{a}}$ & $0.30 \pm 0.0^{\mathrm{a}}$ & $31.16 \pm 2.1^{\mathrm{f}}$ & $2.18 \pm 0.0^{\mathrm{b}}$ & $0.57 \pm 0.0^{\mathrm{a}}$ & $9.90 \pm 0.5^{c}$ \\
\hline A. silvicola & $0.48 \pm 0.0^{\mathrm{a}}$ & $0.27 \pm 0.0^{\mathrm{a}}$ & $39.12 \pm 3.1^{\mathrm{g}}$ & $2.14 \pm 0.0^{\mathrm{b}}$ & $0.48 \pm 0.0^{\mathrm{a}}$ & $11.02 \pm 0.4^{\mathrm{e}}$ \\
\hline Amanita caesarea & $0.71 \pm 0.0^{\mathrm{a}}$ & $0.29 \pm 0.0^{\mathrm{a}}$ & $62.32 \pm 2.9^{j}$ & $4.17 \pm 0.0^{c}$ & $0.91 \pm 0.0^{\mathrm{a}}$ & $17.25 \pm 0.8^{\mathrm{e}}$ \\
\hline A. citrina & $0.57 \pm 0.0^{\mathrm{a}}$ & $0.39 \pm 0.0^{\mathrm{a}}$ & $41.13 \pm 1.1^{\mathrm{h}}$ & $3.35 \pm 0.0^{c}$ & $0.77 \pm 0.0^{\mathrm{a}}$ & $12.93 \pm 0.5^{\mathrm{f}}$ \\
\hline A. fulva & $0.39 \pm 0.0^{\mathrm{a}}$ & $0.21 \pm 0.0^{\mathrm{a}}$ & $39.16 \pm 1.8^{\mathrm{h}}$ & $3.11 \pm 0.0^{c}$ & $0.79 \pm 0.0^{\mathrm{a}}$ & $13.47 \pm 0.6^{\mathrm{g}}$ \\
\hline Cantharellus cibarius & $0.79 \pm 0.0^{\mathrm{a}}$ & $0.33 \pm 0.0^{\mathrm{a}}$ & $63.36 \pm 2.5^{j}$ & $4.45 \pm 0.0^{c}$ & $0.99 \pm 0.0^{\mathrm{a}}$ & $14.25 \pm 0.7^{\mathrm{h}}$ \\
\hline Conocybe tenera & $0.45 \pm 0.0^{\mathrm{a}}$ & $0.20 \pm 0.0^{\mathrm{a}}$ & $35.1 \pm 1.4^{\mathrm{f}}$ & $1.90 \pm 0.0^{\mathrm{b}}$ & $0.35 \pm 0.0^{\mathrm{a}}$ & $7.99 \pm 0.4^{\mathrm{b}}$ \\
\hline Gymnopilus junonius & $0.70 \pm 0.0^{\mathrm{a}}$ & $0.31 \pm 0.0^{\mathrm{a}}$ & $53.17 \pm 3.2^{\mathrm{i}}$ & $3.95 \pm 0.0^{\mathrm{c}}$ & $0.80 \pm 0.0^{\mathrm{a}}$ & $14.12 \pm 0.8^{\mathrm{h}}$ \\
\hline Hygrocybe coccinea & $0.37 \pm 0.0^{\mathrm{a}}$ & $0.25 \pm 0.0^{\mathrm{a}}$ & $30.11 \pm 3.1^{\mathrm{f}}$ & $2.98 \pm 0.02^{\mathrm{b}}$ & $0.37 \pm 0.0^{\mathrm{a}}$ & $10.21 \pm 0.3^{\mathrm{d}}$ \\
\hline H. nivea & $0.38 \pm 0.0^{\mathrm{a}}$ & $0.22 \pm 0.0^{\mathrm{a}}$ & $19.12 \pm 2.1^{\mathrm{e}}$ & $2.14 \pm 0.0^{\mathrm{b}}$ & $0.32 \pm 0.0^{\mathrm{a}}$ & $6.92 \pm 0.5^{\mathrm{a}}$ \\
\hline Inocybe splendens & $0.21 \pm 0.0^{\mathrm{a}}$ & $0.19 \pm 0.0^{\mathrm{a}}$ & $18.32 \pm 2.1^{\mathrm{e}}$ & $2.37 \pm 0.0^{\mathrm{b}}$ & $0.20 \pm 0.0^{\mathrm{a}}$ & $6.39 \pm 0.4^{\mathrm{a}}$ \\
\hline Lactarius pubescens & $0.47 \pm 0.0^{\mathrm{a}}$ & $0.33 \pm 0.0^{\mathrm{a}}$ & $51.19 \pm 3.1^{\mathrm{i}}$ & $3.34 \pm 0.0^{\mathrm{c}}$ & $0.39 \pm 0.0^{\mathrm{a}}$ & $12.59 \pm 0.3^{\mathrm{f}}$ \\
\hline Laccaria laccata & $0.40 \pm 0.0^{\mathrm{a}}$ & $0.30 \pm 0.0^{\mathrm{a}}$ & $39.62 \pm 2.8^{f}$ & $2.51 \pm 0.0^{\mathrm{b}}$ & $0.35 \pm 0.0^{\mathrm{a}}$ & $12.62 \pm 0.6^{\mathrm{f}}$ \\
\hline Lepista nuda & $0.39 \pm 0.0^{\mathrm{a}}$ & $0.20 \pm 0.0^{\mathrm{a}}$ & $23.37 \pm 2.1^{\mathrm{f}}$ & $2.47 \pm 0.0^{\mathrm{b}}$ & $0.34 \pm 0.0^{\mathrm{a}}$ & $7.95 \pm 0.3^{b}$ \\
\hline Lentinus cladopus & $0.75 \pm 0.0^{\mathrm{a}}$ & $0.30 \pm 0.0^{\mathrm{a}}$ & $55.13 \pm 1.9^{\mathrm{i}}$ & $3.90 \pm 0.0^{c}$ & $0.77 \pm 0.0^{\mathrm{a}}$ & $13.72 \pm 0.5^{\mathrm{e}}$ \\
\hline Pleurotus cystidiosus & $0.79 \pm 0.0^{\mathrm{a}}$ & $0.28 \pm 0.0^{\mathrm{a}}$ & $53.20 \pm 2.7^{\mathrm{i}}$ & $3.99 \pm 0.0^{c}$ & $0.82 \pm 0.0^{\mathrm{a}}$ & $15.25 \pm 0.6^{\mathrm{e}}$ \\
\hline Russula lepida & $0.27 \pm 0.0^{\mathrm{a}}$ & $0.20 \pm 0.0^{\mathrm{a}}$ & $30.76 \pm 2.2^{\mathrm{f}}$ & $1.98 \pm 0.0^{\mathrm{b}}$ & $0.29 \pm 0.0^{\mathrm{a}}$ & $6.24 \pm 0.2^{\mathrm{d}}$ \\
\hline R. mairei & $0.23 \pm 0.0^{\mathrm{a}}$ & $0.23 \pm 0.0^{\mathrm{a}}$ & $27.10 \pm 3.1^{\mathrm{f}}$ & $1.14 \pm 0.0^{\mathrm{b}}$ & $0.27 \pm 0.0^{\mathrm{a}}$ & $6.14 \pm 0.2^{\mathrm{d}}$ \\
\hline
\end{tabular}

Values are expressed as mean \pm SE and different letters represent the significant difference in each column with $p \leq 0.05$ according to Tukey's test. 
TABLE 8: $\mathrm{EC}_{50}$ values for different antioxidant assays on twenty wild culinary species collected from northern Himalayas.

\begin{tabular}{|c|c|c|c|c|c|c|}
\hline Species & $\begin{array}{c}\text { DPPH radical } \\
\text { scavenging activity } \\
(\mathrm{mg} / \mathrm{mL})\end{array}$ & $\begin{array}{c}\text { ABTS } \\
(\mathrm{mg} / \mathrm{mL})\end{array}$ & $\begin{array}{l}\text { Reducing } \\
\text { power } \\
(\mathrm{mg} / \mathrm{mL})\end{array}$ & $\begin{array}{c}\mathrm{Fe}^{2+} \text { chelating } \\
\text { activity }(\mathrm{mg} / \mathrm{mL})\end{array}$ & $\begin{array}{l}\text { Scavenging on } \\
\text { superoxide anion } \\
\text { radical }(\mathrm{mg} / \mathrm{mL})\end{array}$ & $\begin{array}{l}\text { FRAP }\left(\mu \mathrm{mol} \mathrm{Fe} e^{2+}\right. \\
\text { equivalents/g DW })\end{array}$ \\
\hline Agaricus arvensis & $2.12 \pm 0.4$ & $3.19 \pm 0.3$ & $2.27 \pm 0.3$ & $1.14 \pm 0.3$ & $1.34 \pm 0.1$ & $1.74 \pm 0.1$ \\
\hline A. campestris & $3.28 \pm 0.5$ & $3.10 \pm 0.4$ & $3.12 \pm 0.5$ & $2.02 \pm 0.2$ & $1.41 \pm 0.5$ & $1.56 \pm 0.3$ \\
\hline A. comtulus & $3.14 \pm 0.2$ & $3.27 \pm 0.3$ & $3.11 \pm 0.6$ & $1.92 \pm 0.1$ & $2.04 \pm 0.5$ & $1.44 \pm 0.1$ \\
\hline A. silvicola & $3.08 \pm 0.3$ & $3.35 \pm 0.5$ & $3.95 \pm 0.2$ & $1.84 \pm 0.2$ & $2.09 \pm 0.4$ & $1.41 \pm 0.0$ \\
\hline Amanita caesarea & $2.02 \pm 0.2$ & $1.45 \pm 0.6$ & $2.44 \pm 0.1$ & $1.40 \pm 0.4$ & $0.44 \pm 0.3$ & $1.86 \pm 0.1$ \\
\hline A. citrina & $3.21 \pm 0.4$ & $3.19 \pm 0.4$ & $2.57 \pm 0.7$ & $2.24 \pm 0.3$ & $1.11 \pm 0.2$ & $1.50 \pm 0.0$ \\
\hline A. fulva & $3.29 \pm 0.3$ & $3.25 \pm 0.3$ & $2.78 \pm 0.2$ & $1.92 \pm 0.5$ & $1.10 \pm 0.3$ & $1.46 \pm 0.2$ \\
\hline Cantharellus cibarius & $1.76 \pm 0.2$ & $1.59 \pm 0.4$ & $1.62 \pm 0.5$ & $1.27 \pm 0.2$ & $0.39 \pm 0.4$ & $1.85 \pm 0.3$ \\
\hline Conocybe tenera & $5.13 \pm 0.2$ & $3.21 \pm 0.6$ & $5.12 \pm 0.3$ & $1.74 \pm 0.5$ & $1.09 \pm 0.2$ & $1.56 \pm 0.0$ \\
\hline Gymnopilus junonius & $2.58 \pm 0.2$ & $2.84 \pm 0.4$ & $1.95 \pm 0.2$ & $2.21 \pm 0.3$ & $1.27 \pm 0.6$ & $0.78 \pm 0.0$ \\
\hline Hygrocybe coccinea & $3.82 \pm 0.2$ & $3.29 \pm 0.5$ & $3.12 \pm 0.8$ & $1.35 \pm 0.2$ & $1.98 \pm 0.2$ & $1.11 \pm 0.0$ \\
\hline H. nivea & $3.64 \pm 0.3$ & $4.26 \pm 0.5$ & $3.11 \pm 0.2$ & $1.45 \pm 0.6$ & $1.94 \pm 0.1$ & $1.13 \pm 0.0$ \\
\hline Inocybe splendens & $4.12 \pm 0.3$ & $3.15 \pm 0.6$ & $5.19 \pm 0.1$ & $1.76 \pm 0.4$ & $1.99 \pm 0.7$ & $1.24 \pm 0.0$ \\
\hline Lactarius pubescens & $2.87 \pm 0.2$ & $3.39 \pm 0.4$ & $4.87 \pm 0.3$ & $1.87 \pm 0.2$ & $2.21 \pm 0.6$ & $1.62 \pm 0.4$ \\
\hline Laccaria laccata & $3.19 \pm 0.4$ & $3.23 \pm 0.3$ & $4.12 \pm 0.2$ & $1.94 \pm 0.6$ & $1.91 \pm 0.2$ & $1.56 \pm 0.0$ \\
\hline Lepista nuda & $3.71 \pm 0.3$ & $3.26 \pm 0.4$ & $4.21 \pm 0.3$ & $2.04 \pm 0.5$ & $1.84 \pm 0.1$ & $1.36 \pm 0.0$ \\
\hline Lentinus cladopus & $2.15 \pm 0.5$ & $2.29 \pm 0.9$ & $2.86 \pm 0.2$ & $2.19 \pm 0.1$ & $1.10 \pm 0.2$ & $1.66 \pm 0.0$ \\
\hline Pleurotus cystidiosus & $2.17 \pm 0.6$ & $2.95 \pm 0.2$ & $2.57 \pm 0.1$ & $2.11 \pm 0.3$ & $1.04 \pm 0.1$ & $1.58 \pm 0.3$ \\
\hline Russula lepida & $3.10 \pm 0.2$ & $3.21 \pm 0.1$ & $4.10 \pm 0.3$ & $2.84 \pm 0.2$ & $1.23 \pm 0.2$ & $1.19 \pm 0.0$ \\
\hline R. mairei & $3.17 \pm 0.3$ & $3.11 \pm 0.1$ & $5.16 \pm 0.2$ & $2.95 \pm 0.3$ & $1.14 \pm 0.1$ & $2.16 \pm 0.0$ \\
\hline
\end{tabular}

Values are expressed as mean \pm SE.

obtained for Hygrocybe nivea $(4.26 \pm 0.5 \mathrm{mg} / \mathrm{mL})$ showing lowest ABTS radical scavenging activities of this species. Reducing power of Cantharellus cibarius $(1.62 \pm 0.5 \mathrm{mg} / \mathrm{mL})$ was measured higher than other species. Higher $\mathrm{EC}_{50}$ values for reducing activity were measured in Inocybe splendens $(5.19 \pm 0.1 \mathrm{mg} / \mathrm{mL})$.

Higher effectiveness in ferrous ion chelating activity was detected in Agaricus arvensis $(1.14 \pm 0.1 \mathrm{mg} / \mathrm{mL})$ and low effectiveness was detected in Russula mairei (2.95 \pm $0.3 \mathrm{mg} / \mathrm{mL})$. Nevertheless, Cantharellus cibarius (1.27 \pm $0.2 \mathrm{mg} / \mathrm{mL})$, Amanita caesarea (1.40 $\pm 0.4 \mathrm{mg} / \mathrm{mL})$, Hygrocybe coccinea $(1.35 \pm 0.2 \mathrm{mg} / \mathrm{mL})$, and $H$. nivea $(1.45 \pm$ $0.6 \mathrm{mg} / \mathrm{mL}$ ) showed lower $\mathrm{EC}_{50}$ values than remaining species. $\mathrm{EC}_{50}$ values of scavenging ability on superoxide radical were found to be maximum in Amanita caesarea $(0.44 \pm 0.3 \mathrm{mg} / \mathrm{mL})$ and minimum in Lactarius pubescens $(2.21 \pm 0.6 \mathrm{mg} / \mathrm{mL})$. Gymnopilus junonius showed maximum FRAP activity with least $\mathrm{EC}_{50}$ values $(0.78 \mathrm{mg} / \mathrm{mL})$ and Russula mairei showed minimum antioxidant activity with high $\mathrm{EC}_{50}$ values $(2.16 \mathrm{mg} / \mathrm{mL})$.

\section{Discussion}

Although there are previous reports on documentation of culinary edible species from the regions native to northern Himalayas but there are no reports on the evaluation studies as well as toxicity status of all these culinary species. The wild edible species Agaricus bisporus, Boletus edulis,
Morchella esculenta, Cordyceps sinensis, and Lentinula edodes which have been extensively worked out in India and other parts of the world for their compositional and medicinal aspects have not been undertaken for investigations presently [37-40]. Compositional studies showed that most of the culinary species were rich in protein, carbohydrates, and low in fat. There are several reports on richness of wild edible mushrooms with protein and carbohydrate contents and low fat levels which directly make them nutritionally rich [24, 25, 41]. Nevertheless, under present studies the differences between the nutrient concentrations of all the species differed but Agaricus arvensis, Pleurotus cystidiosus, Amanita caesarea, Agaricus campestris, Cantharellus cibarius, and Lentinus cladopus showed higher nutrient percentage which is comparable to other wild and commercially cultivated species $[25,42]$. The crude fat content detected in all the species was not found to be significantly different. Crude fibres were detected in appreciable percentage from all the species which make them important in nutritional point of view. The results are in conformity with the previous reports on several wild edible Pleurotus and Lentinus species from northwest India [24, 43]. The species Inocybe splendens, Hygrocybe nivea, and Conocybe tenera were not found to contain higher percentage of nutrients. Although previous reports showed that nutrients composition in wild species is less as compared to cultivated species [25], however Agaricus arvensis, Pleurotus cystidiosus, Amanita caesarea, Agaricus campestris, Cantharellus cibarius, and Lentinus cladopus were 
found to be rich in protein and carbohydrates similar to commercially grown species [25].

Fatty acid composition showed the dominance of UFA over SFA in all the studied mushrooms species, which is in conformity with the other studies [41]. The differences were observed in net amounts in all the species. Unsaturation index of Agaricus arvensis and Lentinus cladopus (0.57 \pm $0.02 \%$ ) was found to be significantly higher than other species Whereas, Inocybe splendens $(0.05 \pm 0.0 \%)$ showed least Unsaturation Index. High UFA shows the medicinal importance of these culinary mushrooms as these increase the HDL cholesterol and decrease LDL cholesterol, triacylglycerol, lipid oxidation, and LDL susceptibility to oxidation [44]. Predominance of UFA over SFA in all the species shows similar results as obtained for other wild and commercially cultivated species $[24,25] . \alpha$ - and $\beta$-tocopherol were detected in higher amounts than third isomer in all the studied species. Similar findings were made in other wild and cultivated species with higher $\alpha$ - and $\beta$-tocopherol than $\gamma$-tocopherol [25]. The high levels of these two compounds correspond with a higher oxidative activity, which is associated with cardiovascular protection [45]. Phenolic compounds were detected in higher amounts than other bioactive compounds. Presence of high phenolic compounds accounts for the high antioxidant properties of all the species [42]. $\beta$-carotene, lycopene, and ascorbic acids were detected in low amounts. Anthocyanidins were also detected from these wild species in appreciable amounts. The presence of these functional medicinal compounds in medicinal and/or edible mushroom is due to habitat or substrates in which these grow to be high in the functional molecules. The categories of these molecules are anthocyanidins, beta-glucans, selenium, ganoderic acid, triterpenes, or cordycepin. The compounds identified in these extracts show that at least a part of the functional compounds in medicinal and/or edible mushroom is due to growing mushrooms on substrates that are high in the functional molecules. To these categories can be added anthocyanidins, beta-glucans, selenium, ganoderic acid, triterpenes, or cordycepin. The amounts of these have been found to vary with the type of extraction as ethanolic extract yields higher amounts of anthocyanidins as compared to methanolic, hot water, and cold water extracts [29].

All the studied species showed significant antioxidant properties measured on the basis of $\mathrm{EC}_{50}$ values. Nevertheless, each species showed different antioxidant activity with highly effective and less effective $\mathrm{EC}_{50}$ values. Better antioxidant properties of some species are due to presence of higher phenolic compounds, $\beta$-carotene, lycopene, ascorbic acids, anthocyanidins, and tocopherol amounts in them. High reducing power of some species is due to the presence of higher amounts of reducers (antioxidants) in them. Presently investigated species are commonly used for culinary purposes in the regions native to northern Himalayas. Many of the species in these regions are not evaluated previously for detailed compositional analysis. Their knowledge is restricted to old aged villagers of the regions and neglected for the commercial exploitations. There are no positive reports on toxicity of these mushrooms analyzed presently; hence these are safe for further experimental work related to drug discovery. All the culinary species contained important and useful nutraceuticals such as unsaturated fatty acids, phenolics, carotenoids, ascorbic acid, tocopherols, and anthocyanidins; besides these, some important amino acids were detected in these mushrooms which could be used for the purpose of being used as functional ingredients. Since nutraceuticals are powerful in maintaining and promoting health, longevity, and life quality, the commercial exploitation of these species will certainly create an impact on nutritional therapy and also will be beneficial today's food industry. Direct use of these species for consumption and other culinary aspects is safe and health promoting with advantage of the additive effects of all the bioactive and antioxidant compounds present in these species.

\section{Abbreviations}

$\mathrm{AlCl}_{3}$ : Aluminum trichloride

ANOVA: Analysis of variance

D.W.: Distilled water

DPPH: 2,2-Diphenyl-1-picrylhydrazyl

$\mathrm{FeCl}_{3}$ : Ferric chloride

FRAP: Ferric reducing antioxidant power

g: $\quad$ Grams

GAEs: Gallic acid equivalents

GC: Gas Chromatography

$\mathrm{HCl} \quad$ Hydrochloric acid

$\mathrm{H}_{2} \mathrm{O}$ : Water

$\mathrm{H}_{3} \mathrm{PO}_{4}$ : Phosphoric acid

HPLC: High performance liquid chromatography

$\mathrm{K}_{2} \mathrm{HPO}_{4}$ : Potassium hydrogen, phosphate

L: $\quad$ Liters

m: $\quad$ Meters

mg: $\quad$ Milligrams

mL: $\quad$ Milliliters

mM: Millimolar

MTBE: Methyl tertiary-butyl ether

MUFA: Monounsaturated fatty acids

$\mathrm{N}$ : Nitrogen

$\mathrm{NaOH}$ : Sodium hydroxide

ND: $\quad$ Not detected

${ }^{\circ} \mathrm{C}$ : $\quad$ Degree centigrade

PUFA: Polyunsaturated fatty acids

rpm: Rotation per minute

SFA: $\quad$ Saturated fatty acids

TPTZ: Tripyridyltriazine

vol.: Volume

\%: $\quad$ Percent

$\mu \mathrm{g}: \quad$ Microgram

$\mu \mathrm{M}: \quad$ Micromolar

UI: Unsaturation index

UFA: Unsaturated fatty acids

UPLC: Ultra performance liquid chromatography.

\section{Conflict of Interests}

The authors declare that there is no conflict of interests regarding the publication of this paper. 


\section{Acknowledgment}

The authors wish to thank Science and Engineering Board, Department of Science and Technology, New Delhi, for research Grant (SB/FT/LS-04/2013) to carry out present studies.

\section{References}

[1] W. M. Breene, "Nutritional and medicinal value of specialty mushrooms," Journal of Food Protection, vol. 53, pp. 883-894, 1990.

[2] S. Chang and P. Miles, "Mushroom biology-a new discipline," Mycologist, vol. 6, no. 2, pp. 64-65, 1992.

[3] P. Manzi, L. Gambelli, S. Marconi, V. Vivanti, and L. Pizzoferrato, "Nutrients in edible mushrooms: an inter-species comparative study," Food Chemistry, vol. 65, no. 4, pp. 477-482, 1999.

[4] P. Bobek, O. Ozdín, and M. Mikus, "Dietary oyster mushroom (Pleurotus ostreatus) accelerates plasma cholesterol turnover in hypercholesterolaemic rats," Physiological Research, vol. 44, no. 5, pp. 287-291, 1995.

[5] P. Bobek and S. Galbavý, "Hypocholesterolemic and antiatherogenic effect of oyster mushroom (Pleurotus ostreatus) in rabbits," Nahrung, vol. 43, no. 5, pp. 339-342, 1999.

[6] S. Khatun, A. Islam, U. Cakilcioglu, and N. Chatterjee, "Research on mushroom as a potential source of nutraceuticals: a review on Indian perspective," American Journal of Experimental Agriculture, vol. 2, no. 1, pp. 47-73, 2012.

[7] J. A. Vaz, L. Barros, A. Martins, J. S. Morais, M. H. Vasconcelos, and I. C. F. R. Ferreira, "Phenolic profile of seventeen portuguese wild mushrooms," LWT: Food Science and Technology, vol. 44, no. 1, pp. 343-346, 2011.

[8] J. A. Vaz, L. Barros, A. Martins, C. Santos-Buelga, M. H. Vasconcelos, and I. C. F. R. Ferreira, "Chemical composition of wild edible mushrooms and antioxidant properties of their water soluble polysaccharidic and ethanolic fractions," Food Chemistry, vol. 126, no. 2, pp. 610-616, 2011.

[9] T. Ozen, C. Darcan, O. Aktop, and I. Turkekul, "Screening of antioxidant, antimicrobial activities and chemical contents of edible mushrooms wildly grown in the Black Sea region of Turkey," Combinatorial Chemistry \& High Throughput Screening, vol. 14, no. 2, pp. 72-84, 2011.

[10] V. E. C. Ooi and F. Liu, "A Review of pharmacological activities of mushroom polysaccharides," International Journal of Medicinal Mushrooms, vol. 1, no. 3, pp. 195-206, 1999.

[11] S. P. Wasser and A. L. Weis, "Medicinal properties of substances occurring in higher Basidiomycete mushroom: current perspective," International Journal of Medicinal Mushrooms, vol. 1, pp. 31-62, 1999.

[12] P. M. Kidd, "The use of mushroom glucans and proteoglycans in cancer treatment," Alternative Medicine Review, vol. 5, no. 1, pp. $4-27,2000$.

[13] C. Israilides and A. Philippoussis, "Bio-technologies of recycling agro-industrial wastes for the production of commercially important fungal polysaccharides and mushrooms," Biotechnology and Genetic Engineering Reviews, vol. 20, pp. 247-259, 2003.

[14] T. Mizuno, "Bioactive biomolecules of mushrooms: food function and medicinal effect of mushroom fungi," Food Reviews International, vol. 11, no. 1, pp. 5-21, 1995.

[15] Y. Kabir and S. Kimura, "Dietary mushrooms reduce blood pressure in spontaneously hypertensive rats (SHR)," Journal of
Nutritional Science and Vitaminology, vol. 35, no. 1, pp. 91-94, 1989.

[16] J.-L. Mau, S.-Y. Tsai, Y.-H. Tseng, and S.-J. Huang, "Antioxidant properties of hot water extracts from Ganoderma tsugae Murrill," LWT-Food Science and Technology, vol. 38, no. 6, pp. 589597, 2005.

[17] A. Smânia, F. D. Monache, E. F. A. Smânia, M. L. Gil, L. C. Benchetrit, and F. S. Cruz, "Antibacterial activity of a substance produced by the fungus Pycnoporus sanguineus (Fr.) Murr," Journal of Ethnopharmacology, vol. 45, no. 3, pp. 177-181, 1995.

[18] W. Andlauer and P. Fürst, "Nutraceuticals: a piece of history, present status and outlook," Food Research International, vol. 35, no. 2-3, pp. 171-176, 2002.

[19] C. L. Kruger and S. W. Mann, "Safety evaluation of functional ingredients," Food and Chemical Toxicology, vol. 41, no. 6, pp. 793-805, 2003.

[20] P. H. Mattila, V. I. Piironen, E. J. Uusi-Rauva, and P. E. Koivistoinen, "Vitamin D contents in edible mushrooms," Journal of Agricultural and Food Chemistry, vol. 42, no. 11, pp. 2449-2453, 1994.

[21] R. P. Tewari, "Mushroom, their role in nature and society", in Frontiers in Mushroom Biotechnology, R. D. Rai, R. C. Upadhyay, and S. R. Sharma, Eds., pp. 1-8, NRCM, Chambaghat, India, 2005.

[22] K. C. Semwal, S. L. Stephenson, V. K. Bhatt, and R. P. Bhatt, "Edible mushrooms of the Northwestern Himalaya, India: a study of indigenous knowledge, distribution and diversity," Mycosphere, vol. 5, no. 3, pp. 440-461, 2014.

[23] E. V. Crisan and A. Sands, "Edible mushrooms: nutritional value," in The Biology and Cultivation of Edible Mushrooms, S. T. Chang and W. A. Hayes, Eds., pp. 137-165, Academic Press, New York, NY, USA, 1978.

[24] N. S. Atri, S. K. Sharma, R. Joshi, A. Gulati, and A. Gulati, "Nutritional and neutraceutical composition of five wild culinary-medicinal species of genus Pleurotus (Higher Basidiomycetes) from Northwest India," International Journal of Medicinal Mushrooms, vol. 15, no. 1, pp. 49-56, 2013.

[25] L. Barros, T. Cruz, P. Baptista, L. M. Estevinho, and I. C. F. R. Ferreira, "Wild and commercial mushrooms as source of nutrients and nutraceuticals," Food and Chemical Toxicology, vol. 46, no. 8, pp. 2742-2747, 2008.

[26] M. Nagata and I. Yamashita, "Simple method for simultaneous determination of chlorophyll and carotenoids in tomato fruit," Nippon Shokuhin Kogyo Gakkaishi, vol. 39, no. 10, pp. 925-928, 1992.

[27] V. L. Singleton and J. A. Rossi, "Colorimetric detection of total phenolics with phosphomolybdic-phosphotungstic acid reagents," American Journal of Enology and Viticulture, vol. 16, pp. 144-158, 1965.

[28] L. K. Jagadish, V. Venkata Krishnan, R. Shenbhagaraman, and V. Kaviyarasan, "Comparitive study on the antioxidant, anticancer and antimicrobial property of Agaricus bisporus (J. E. Lange) Imbach before and after boiling," African Journal of Biotechnology, vol. 8, no. 4, pp. 654-661, 2009.

[29] E. Vamanu and S. Nita, "Antioxidant capacity and the correlation with major phenolic compounds, anthocyanin, and tocopherol content in various extracts from the wild edible Boletus edulis mushroom," BioMed Research International, vol. 2013, Article ID 313905, 11 pages, 2013.

[30] E. Vamanu, "Biological activities of the polysaccharides produced in submerged culture of two edible Pleurotus ostreatus 
mushrooms," Journal of Biomedicine and Biotechnology, vol. 2012, Article ID 565974, 8 pages, 2012.

[31] P. L. Li, L. Huo, W. Su et al., "Free radical-scavenging capacity, antioxidant activity and phenolic content of Pouzolzia zeylanica," Journal of the Serbian Chemical Society, vol. 76, no. 5, pp. 709-717, 2011.

[32] C. Papuc, M. Crivineanu, G. Goran, V. Nicorescu, and N. Durdun, "Free radicals scavenging and antioxidant activity of European mistletoe (Viscum album) and European birthwort (Aristolochia clematitis)," Revista de Chimie, vol. 61, no. 7, pp. 619-622, 2010.

[33] V. O. Oyetayo, C. Dong, and Y. Yao, "Antioxidant and antimicrobial properties of aqueous extract from Dictyophora indusiata," The Open Mycology Journal, vol. 3, no. 1, pp. 20-26, 2009.

[34] S. Marklund and G. Marklund, "Involvement of the superoxide anion radical in the autoxidation of pyrogallol and a convenient assay for superoxide dismutase," European Journal of Biochemistry, vol. 47, no. 3, pp. 469-474, 1974.

[35] I. F. F. Benzie and J. J. Strain, "The ferric reducing ability of plasma (FRAP) as a measure of 'antioxidant power': the FRAP assay," Analytical Biochemistry, vol. 239, no. 1, pp. 70-76, 1996.

[36] D. J. Huang, b. Ou, and R. L. Prior, "The chemistry behind antioxidant capacity assays," Journal of Agricultural and Food Chemistry, vol. 53, no. 6, pp. 1841-1856, 2005.

[37] P. Manzi, A. Aguzzi, and L. Pizzoferrato, "Nutritional value of mushrooms widely consumed in Italy," Food Chemistry, vol. 73, no. 3, pp. 321-325, 2001.

[38] P. Manzi, S. Marconi, A. Aguzzi, and L. Pizzoferrato, "Commercial mushrooms: nutritional quality and effect of cooking," Food Chemistry, vol. 84, no. 2, pp. 201-206, 2004.

[39] I. P. Krbavčić and I. C. Barić, "Influence of deep fat frying on some nutritional parameters of novel food based on mushrooms and fresh soft cheese," Food Chemistry, vol. 84, no. 3, pp. 417-419, 2004.

[40] D. Agrahar-Murugkar and G. Subbulakshmi, "Nutritional value of edible wild mushrooms collected from the Khasi hills of Meghalaya," Food Chemistry, vol. 89, no. 4, pp. 599-603, 2005.

[41] V. A. Díez and A. Alvarez, "Compositional and nutritional studies on two wild edible mushrooms from northwest Spain," Food Chemistry, vol. 75, no. 4, pp. 417-422, 2001.

[42] L. Barros, M.-J. Ferreira, B. Queirós, I. C. F. R. Ferreira, and P. Baptista, "Total phenols, ascorbic acid, $\beta$-carotene and lycopene in Portuguese wild edible mushrooms and their antioxidant activities," Food Chemistry, vol. 103, no. 2, pp. 413-419, 2007.

[43] S. K. Sharma and N. S. Atri, "Nutraceutical composition of wild species of genus Lentinus Fr. from Nothern India," Current Research in Environmental \& Applied Mycology, vol. 4, pp. 11-32, 2014.

[44] P. J. Kanu, K. Zhu, J. Baby Kanu, H. Zhou, H. Qian, and K. Zhu, "Biologically active components and nutraceuticals in sesame and related products: a review and prospect," Trends in Food Science and Technology, vol. 18, no. 12, pp. 599-608, 2007.

[45] F. S. Reis, E. Pereira, L. Barros, M. J. Sousa, A. Martins, and I. C. F. R. Ferreira, "Biomolecule profiles in inedible wild mushrooms with antioxidant value," Molecules, vol. 16, no. 6, pp. 4328-4338, 2011. 

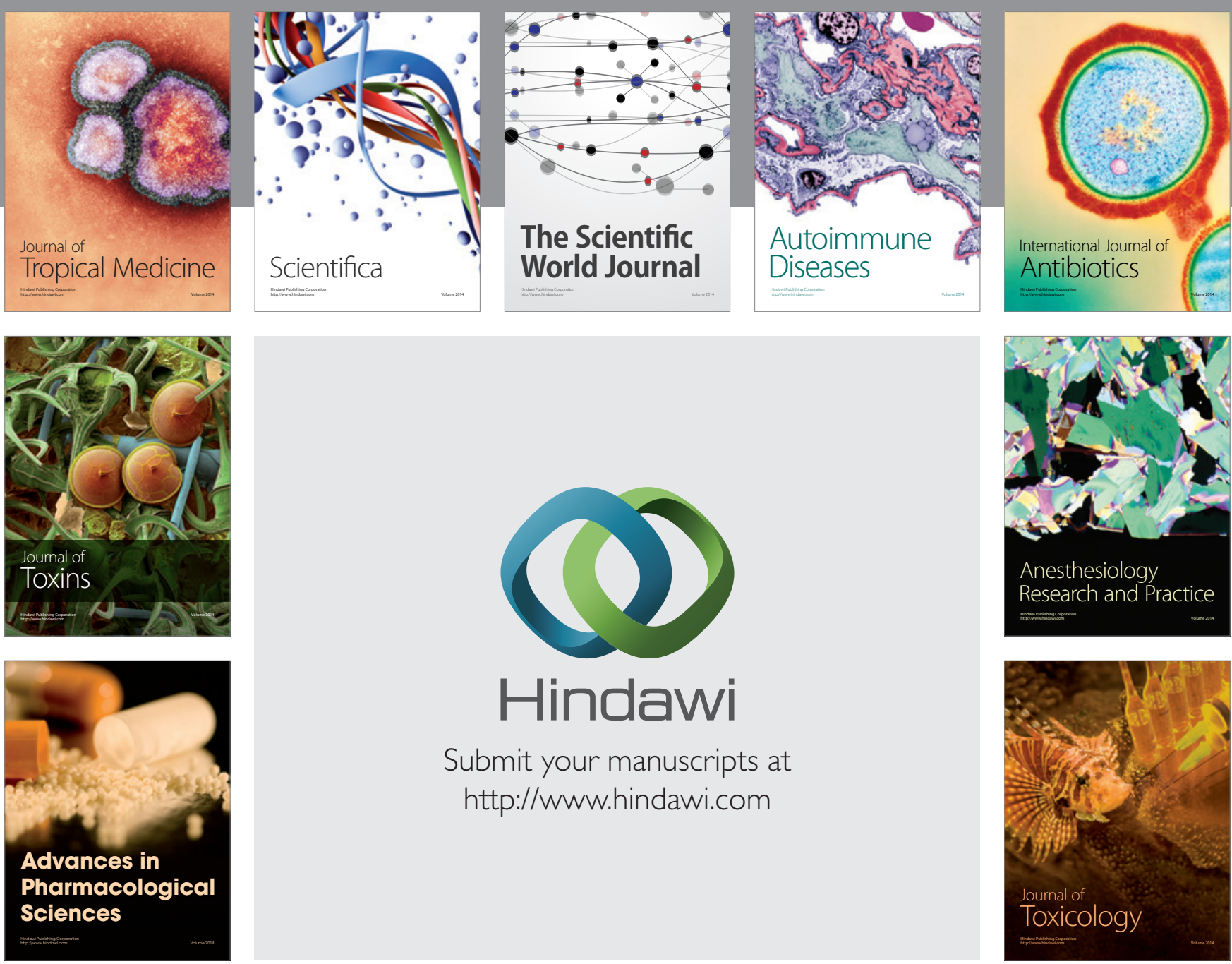

\section{Hindawi}

Submit your manuscripts at

http://www.hindawi.com
